Article

\title{
Seed Networks for Upscaling Forest Landscape Restoration: Is It Possible to Expand Native Plant Sources in Brazil?
}

\author{
Danilo I. de Urzedo ${ }^{1, *}$, Fatima C.M. Piña-Rodrigues ${ }^{2}{ }^{\mathbb{D}}$, Rafael Feltran-Barbieri ${ }^{3}$, \\ Rodrigo G.P. Junqueira ${ }^{4}$ and Robert Fisher ${ }^{1,5}$ \\ 1 School of Geosciences, the University of Sydney, Sydney 2006, Australia; robert.fisher@sydney.edu.au \\ 2 Environmental Science Department, Universidade Federal de São Carlos, 18052-780 Sorocaba, Brazil; \\ fpina@ufscar.br \\ 3 World Resources Institute Brazil, 05422-030 São Paulo, Brazil; rafael.barbieri@wri.org \\ 4 Instituto Socioambiental, 70297-40 Brasília, DF, Brazil; rodrigojunqueira@socioambiental.org \\ 5 Tropical Forests and People Research Centre, University of the Sunshine Coast, \\ Sunshine Coast 4558, Australia \\ * Correspondence: danilo.urzedo@gmail.com
}

Received: 12 January 2020; Accepted: 24 February 2020; Published: 27 February 2020

\begin{abstract}
In this paper, we explore how diverse community networks in Brazil have locally advanced seed production and institutional systems to enhance a restoration economy. By focusing on the experiences of the six major native seed suppliers in Amazonia, the Cerrado, and the Atlantic Forest, we estimate the capacity to scale-up community-based systems to meet a large-scale restoration target as a rural development strategy. Over one decade, 1016 collectors traded 416.91 tonnes of native seeds representing, on average, 31.41 kilos yearly and USD 256.5 as household income. Based on this well documented empirical evidence, we estimate that Brazil's restoration goal would require from 3.6 to 15.6 thousand tonnes of native seeds depending on the share of each restoration method adopted with potential work opportunities for 13.2 to 57.1 thousand collectors yearly and total income from USD 34 to 146 million. We argue that community networks represent feasible arrangements for increasing the availability of plant material sources which provide high socio-economic benefits. For scaling up native seed sources, we suggest the following key strategies: (i) government incentives and subsidies; (ii) enforcement of ecosystem restoration; (iii) community participation; (iv) adaptation of the seed regulations; (v) technological development; and (vi) seed market diversification.
\end{abstract}

Keywords: ecological restoration; native seed; seedlings; community networks; livelihoods

\section{Introduction}

If current patterns of land use and deforestation are continued, one billion hectares of native vegetation will be cleared by 2050 to meet global food production [1]. Coincidentally, there are at least one billion hectares of degraded land worldwide, which presents opportunities for land restoration [2]. Forest landscape restoration (FLR) has emerged as a global action to recover the functionality of degraded ecosystems with the potential capacity to provide multiple environmental, social, and economic benefits [3]. Reversing ecosystem degradation can provide more than one third of the climate mitigation required to increase carbon storage and avoid greenhouse gas emissions by 2030 [4].

FLR encourages the participation of multiple stakeholders in creating inclusive interventions for recovering the ecological integrity in degraded lands combined with well-being improvements for local people [5-7]. Although interventions on land-use practices could make a significant contribution to adapting to and mitigating environmental changes, restoration actions have attracted limited 
political attention and a lack of financial investments [8]. A range of global agreements and debates on environmental conservation have provided an unprecedented platform for the ambitious task of promoting landscape restoration actions, and the motivation for that is clear: just behind forest conservation, restoration is the cheapest and most effective action to mitigate climate change, especially if replacing degraded or abandoned lands $[9,10]$. The potential capacity of restoration to transform environmental and social inequalities has mobilized dozens of countries to establish ambitious pledges for recovering 350 million hectares of degraded lands by 2030, such as the Bonn Challenge [11], the New York Declaration on Forests [12], and the 2015 United Nations Climate Change Conference (UNFCCC COP21)-Paris Agreement [13]. The most extensive worldwide restoration programs must be implemented in tropical regions where there is the highest feasibility for recovery of ecosystem services [14].

Although the aspiring FLR approach has promoted ecosystem services as a crucial strategy for achieving sustainable development, restoration projects are frequently failing because of top-down systems, absence of institutional arrangements, and poor local participation in decision-making processes [15,16]. A global assessment demonstrated that half of the restoration actions are merely plantations of commercial trees resulting in a lack of ecological functionality [8]. This reality is compounded by a worldwide shortage of high-quality native seed for enhancing biodiversity [17,18].

The current availability of plant material sources is considered insufficient $[19,20]$ for meeting the global demand for hundreds of thousands of tonnes of native seed for large-scale restoration goals [18]. In tropical regions, the use of highly diverse native species in FLR is severely limited by a lack of seed biology knowledge [21], the poor performance of the restoration market [22], a low level of incorporation of local knowledge [18], power centralized on governments [23-25] and the necessity to develop applied technologies $[26,27]$. Over recent decades, a wide range of seed programs has emerged in the tropics to overcome native seed scarcity [28] linked with local communities who own the biodiversity knowledge and traditionally collect and exchange plant materials [19]. Initiatives and organizations have engaged in seed production to connect stakeholders and exchange knowledge and technologies at different levels [29]. Key stakeholders include businesses, investors, governments, researchers, universities, non-governmental organizations (NGOs), and local communities [30]. Community networks have linked a diverse group of collectors who have harvested, processed, and stored seeds with restoration consumers who need seed for mandatory compliance [31,32].

For implementing FLR projects, Latin American countries have a competitive position because of the lowest costs for reducing carbon emissions by decreasing deforestation and restoring degraded lands $[10,33]$. The initiative 20x20 mobilized multiple stakeholders to restore 50 million hectares of degraded lands by 2030 in 17 Latin American and Caribbean countries [34]. Among the national pledges, Brazil assumed leadership with the ambitious commitment to restore 12 million hectares by 2030 which is implemented by a complex institutional framework [35]. The restoration market in Brazil is driven by the legal requirements for land restoration on private proprieties established by the Forest Code [36]. Brazil has well-consolidated experience in developing community-based seed production going back to the 2000s, with a relevant demonstration of how local participation and institutions can enhance supply and design instruments for benefits sharing [37]. Although suppliers have developed innovative seed production systems on the ground, there are still various barriers to boosting seed sources, including the high level of informality and restrictive regulations, unstable restoration markets and lack of public participation in policy decision-making processes [24].

We argue that community-based systems can boost diverse native plant material supply for scaling up restoration actions while achieving significant livelihood improvements. The paper proceeds in the following manner: we first (a) evaluate how the current shortage of native seed in markets is socially and politically constructed based on historical power relationships that shaped policies, regulations, and incentives; (b) secondly, we assess seed production systems in different regions of Brazil; and then (c) we estimate the native seed source necessary to meet Brazil's restoration targets and potential 
socioeconomic impacts. We finally discuss critical strategies for the governance of large-scale native seed supply for the long-lasting restoration market.

\section{Methods}

We first conducted a literature review of the native seed sector in Brazil assessing scientific publications, official documents and reports of Brazil's Forest Seed Committee. The combination of databases contributed to explaining the historical development of the formal institutions and the development of the forest seed industry in Brazil. Secondly, we assessed the outcomes of operations of community networks through the data from the six major seed networks situated in three Brazilian Biomes-Amazon, Cerrado, and Atlantic Forest. We analyzed qualitative descriptions of the local activities, and quantitative outcomes (seed production, number of collectors, species supplied, and income distributed) of Xingu, Portal, Cerrado de Pé, Tupygua, Arboretum, and the Vale do Ribeira Seed Network.

Based on the databases of these six seed networks, from 2007 to 2018, we estimated the total amount of seed (tonnes), the number of seed collectors, the collector productivity (capacity of seed collection $\mathrm{kg} /$ collector) and income generated using an unbalanced panel regression. We then extrapolated those indicators to provide the first-ever assessment of the number of seeds and the number of collectors that would be required to meet the Brazilian commitments to restore 12 million hectares. First, we designed five restoration scenarios (Table 1) of different shares of direct seeding, seedling planting and natural regeneration adapted from the National Plan for the Recovery of Native Vegetation (Planaveg) [35]. We assessed ten years of germination database of the Institute of Forestry (Sao Paulo State, Brazil) encompassing 122 native species and 1941 germination tests, we estimated different expected values of germination in mixed-seeds packs randomly combining 80 of the 122 species available, using the Monte Carlo Markov chain (Figure 1). We estimated confidence intervals for germination rates by species and for mixed-seeds packs randomly combining 80 out of the 122 species available, in 40,000 repetitions, to minimize under or overvaluation due to species-specific bias. Survival rates of mixed seeds in the field, losses in nurseries, and seedling deaths up to four years after restoration implementation were considered based on the literature [38-41] in order to build different baselines on seed production (supply effort). No improvement in native seeds technology, seed production, or supply chain was considered. To estimate the total numbers of native seeds, collectors and amount of income, the coefficients provided by the unbalanced panel regression model were used to achieve each restorations scenario. Detailed statistical methods are described in Supplementary Materials B. We also elaborated key strategies for upscaling seed sources through the identification of ways the empirical evidence of the seed networks can assist to overcome the current shortage of plant material. The strategies were designed to inform a set of essential actions that must be taken by multiple stakeholders to implement FLR and achieve diverse goals.

Table 1. Restoration scenarios of different technical interventions for restoring 12 million hectares of degraded lands in Brazil, including the percentages to be restored by total planting, seedlings planting, direct seeding involving a mix of native seeds and natural regeneration.

\begin{tabular}{|c|c|c|c|c|}
\hline \multirow{2}{*}{ Scenario } & \multicolumn{4}{|c|}{ Ecosystem Restoration Techniques (\%) } \\
\hline & $\begin{array}{c}\text { Total Planting } \\
\text { (1.666 Seedlings/ha }{ }^{-1} \text { ) }\end{array}$ & $\begin{array}{c}\text { Enrichment } \\
\left(600 \text { Seedlings/ha }{ }^{-1}\right)\end{array}$ & $\begin{array}{c}\text { Direct Seeding } \\
\left(23.3 \mathrm{~kg} \text { Seeds } / \mathrm{ha}^{-1}\right)\end{array}$ & $\begin{array}{c}\text { Natural } \\
\text { Regeneration }\end{array}$ \\
\hline 1 & 50.0 & 20.0 & 5.0 & 25.0 \\
\hline 2 & 40.0 & 20.0 & 2.5 & 37.5 \\
\hline 3 & 30.0 & 20.0 & 1.25 & 48.75 \\
\hline 4 & 20.0 & 22.5 & 1.0 & 56.5 \\
\hline 5 & 20.0 & 25.0 & 1.0 & 54.0 \\
\hline
\end{tabular}

Source: Adapted from Planaveg [35]. 


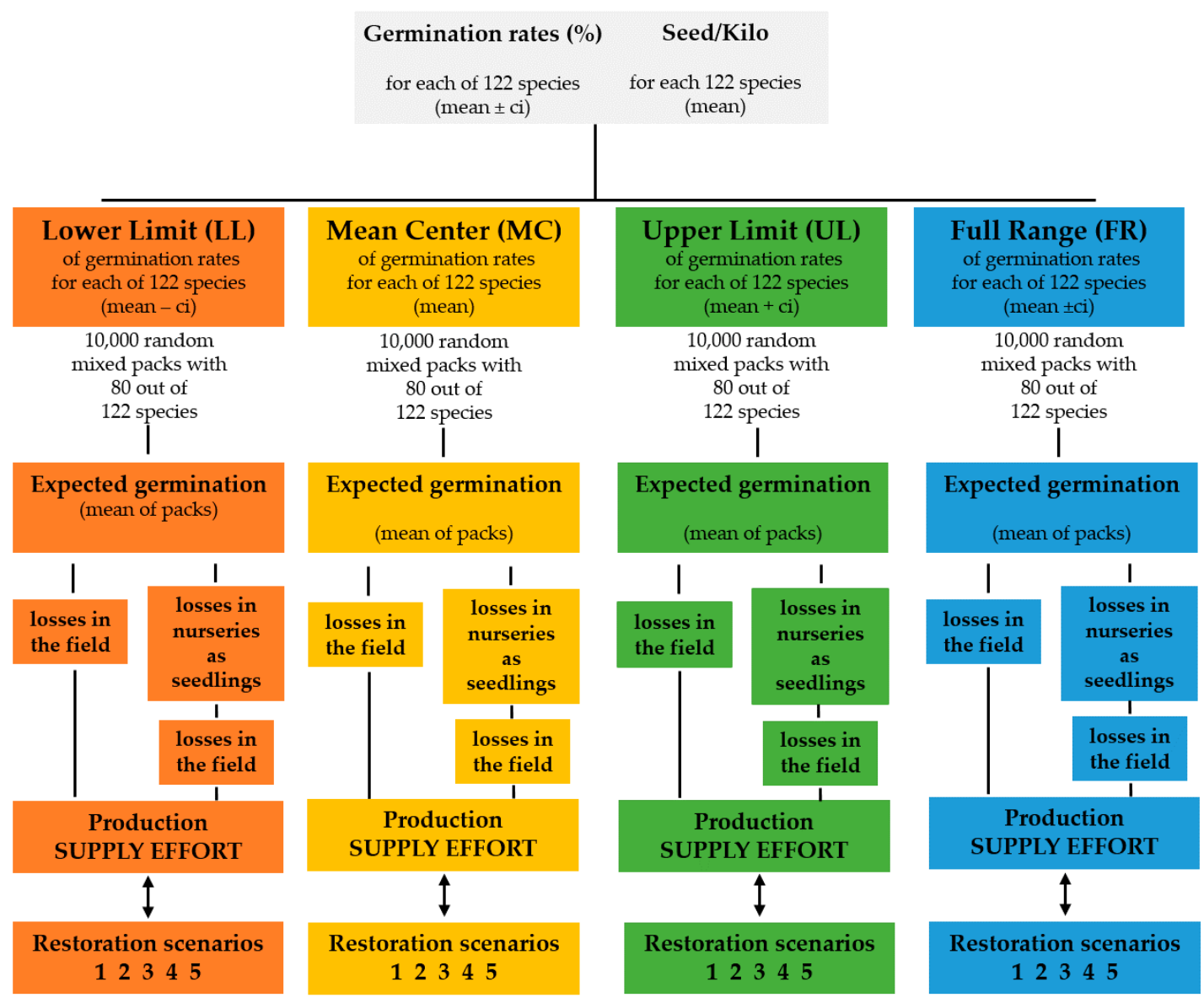

Figure 1. Steps to estimate the seed source required to meet Brazil's restoration pledge in five restoration scenarios (Table 1). Supply effort is the total amount of seed needed, given the amount of estimated seed that could survive up to four years after restoration. $\mathrm{CI}$ is the confidence interval for the mean.

\section{Results}

\subsection{Reasons for the Shortage of Native Seeds}

The forest seed supply arrangements in Brazil emerged from a national economic program from the mid- $20^{\text {th }}$ century to promote the development of the forest industry to address the domestic demand for wood [42]. For enhancing tree farming, the government provided financial incentives to boost private investments by Law 5106/1966 [43], while public research institutes and universities were responsible for advancing technical approaches. Although Brazil holds more than 43 thousand native plant species [44], the national forestry programs actively invested in only two genera of exotic species for upscaling wood, paper, and cellulose production. International and domestic programs on forest genetic improvement were responsible for selecting and supplying high-yield plant materials, mostly of Eucalyptus and Pinus [45]. Consequently, one of the most cost-effective forest industries in the world was implemented in Brazil [46]. However, the lack of forest genetic resources available for commercial purposes in the country required import of tree seed to meet the demands of large-scale tree farming. For controlling the introduction of plant materials in Brazil and the quality of the sources, the federal government established the Law 6507/1977 [47]. After 25 years, the first seed regulation was replaced by Law 10,711/2003 [48]. The National Seed and Seedling Registry (RENASEM) focused on the creation of a national system for seed and seedling production and trade with specific accreditation of producers, laboratories, and other actors.

The earliest attention towards the development of a substantial sector for native plant material supply in Brazil was raised in the context of the global environmental debates at the beginning 
of the 1990s. International environmental debates (e.g., the Earth Summit) reinforced the need for implementation and enforcement of the environmental regulations in Brazil, such as the mandatory restoration on private properties required by the former Forest Code [49]. Since planting tree seedlings was the most common practice for restoring tropical forests [50,51], Brazilian programs boosted private and municipal nurseries to meet restoration market demand [52]. However, these programs failed due to the low diversity of plant material sources and lack of native seed suppliers. Thus, the Ministry of the Environment supported the formation of 'seed networks', as a collaborative strategy between governmental environmental agencies, universities, nurseries and local communities for upscaling native seed sources. In 2001, the federal government financed the creation of seed networks in the Brazilian biomes for developing native seed technologies, capacity development, and local participation [24]. Initially, eight networks were formed to spread scientific knowledge and capacity building to develop a native seed industry. However, after the end of national investments, most of these networks fragmented because these initiatives-operated mostly by universities and research institutes-were not able to develop trade schemes. These experiences contributed to the second generation of native seed networks, which was structured from 2007 in different Brazilian regions, focused on grassroots actions and community participation to meet the regional restoration markets. Although seed networks have engaged diverse actors for plant material supply, collectors and producers have remained unable to attend to the legal requirements to formalize their seed production. In 2018, the RENASEM had the official registration of only 264 collectors, 277 seedling producers, and 12 seed testing laboratories (Supplementary Materials A).

\subsection{Assessment of Seed Supply Systems}

In this section, we explore the common successful operational factors among six different suppliers responsible for promoting productive systems for scaling up seed sources and creating place-specific livelihood outcomes. We present an overall perspective on the significant activities of the Xingu, Portal, Cerrado de Pé, Tupygua, Arboretum, and Vale do Ribeira seed networks. The community networks produced a total of 416.9 tonnes of native seeds by 1016 collectors between 2007 and 2018 (Table 2). The unbalanced panel regression showed that each collector was able to collect $30.41 \pm 8.58$ kilos of mixed seeds per year $(p<0.01)$. The six initiatives have in common the community-based organization but exhibit an entirely different social context distribution of labor, land tenure, and sites of seed collections. Differences are even more pronounced between Indigenous and non-Indigenous communities. Despite this, we found no difference in the capacity of seed collection $(p<0.96)$.

Table 2. Performance of six major seed networks in terms of the quantity of seed traded, native species, seed collectors, and cash income in different regions of Amazonia, Cerrado and Atlantic Forest until and including 2018.

\begin{tabular}{|c|c|c|c|c|c|c|}
\hline Seed Network & Ecosystem & $\begin{array}{c}\text { Creation } \\
\text { (year) }\end{array}$ & $\begin{array}{l}\text { Seed Supplied } \\
\text { (tonnes) }\end{array}$ & $\begin{array}{c}\text { Native } \\
\text { Species }(n)\end{array}$ & $\begin{array}{c}\text { Seed } \\
\text { Collectors }(n)\end{array}$ & $\begin{array}{l}\text { Cash Income } \\
\text { (USD) }\end{array}$ \\
\hline Xingu & Amazon & 2007 & 219.7 & 214 & 568 & $1,323,616$ \\
\hline Portal & Amazon & 2010 & 142.7 & 183 & 250 & 871,484 \\
\hline Cerrado de Pé & $\begin{array}{l}\text { Tropical } \\
\text { savanna }\end{array}$ & 2012 & 36.6 & 72 & 66 & 56,120 \\
\hline Tupygua & $\begin{array}{l}\text { Atlantic } \\
\text { Forest }\end{array}$ & 2012 & 12.96 & 94 & 89 & 80,648 \\
\hline Arboretum & $\begin{array}{l}\text { Atlantic } \\
\text { Forest }\end{array}$ & 2015 & 4.82 & 232 & 29 & 76,143 \\
\hline Vale do Ribeira & $\begin{array}{l}\text { Atlantic } \\
\text { Forest }\end{array}$ & 2017 & 0.13 & 19 & 14 & 3378 \\
\hline \multicolumn{3}{|c|}{ Total } & 416.91 & - & 1016 & $2,411,389$ \\
\hline
\end{tabular}

These initiatives involve diverse actors playing various roles for promoting native seed supply and restoration actions (Figure 2). Seed networks connect local communities who are responsible for supplying native seed to seed buyers who are required by law to restore degraded lands. Although 
each organization has specific institutional systems shaped by local context and particular stakeholders, these experiences provide similar key lessons about ways to stimulate active participation and benefit-sharing. We identified five successful approaches implemented by community seed suppliers that we explore in this section, encompassing: (i) engagement and advocacy for implementation of land restoration actions; (ii) technical and institutional development linked to local knowledge; (iii) support for livelihood improvements through household income generation; (iv) continuous capacity building; and (v) applied research to address technical issues.

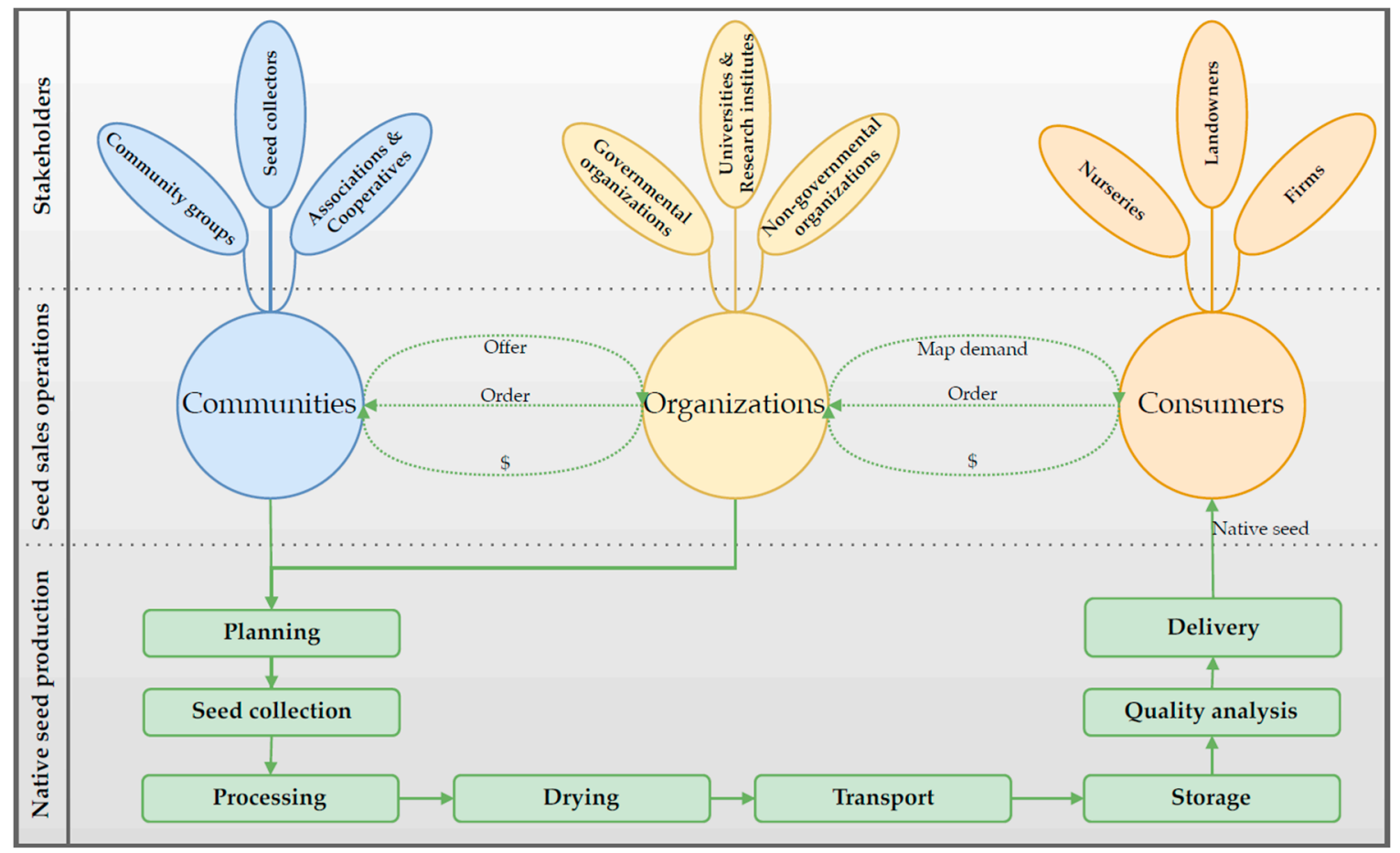

Figure 2. Community networks linking local communities, organizations, and seed buyers for ecosystem restoration in Brazil.

In Brazil, the most prominent restoration market is the mandatory restoration of degraded lands on private properties as required by the Forest Code [36]. While the formal institutions oblige that landowners and companies restore and protect native vegetation, coalitions of stakeholders are essential for effective implementation through different regional strategies. The seed suppliers traded 416.91 tonnes of seeds with 1016 collectors in Amazonia, Cerrado, and Atlantic Forest over the last decade based on the development of regional markets (Table 2). These social mobilizations generally aim to connect seed buyers for long-term partnerships and to create a broader network with collective commitments. In the pioneering case of the Upper Xingu region in Amazonia, the Y Ikatu Xingu campaign ('Save the Good Water of Xingu' in Kamayurá Indigenous language) mobilized farmers to ensure compliance with land restoration requirements [53]. The seed demanded for initial restoration projects created the Xingu Seed Network in 2007 through the participation of diverse local communities ('Local community' is a generic term that refers to people who inhabit a particular location, including Indigenous peoples, maroons, traditional communities, small farmers, settler farmers. The definition of Indigenous and traditional communities is based on Decree no. 6040/2007 [54]), including Indigenous and traditional communities, smallholders, and urban residents for native seed collection [32]. After more than one decade, this organization, composed of 568 collectors, became the most significant commercial native seed producer in Brazil (over 25 tonnes yearly), and became the key reference for other national initiatives. 
In the case of the Xingu Seed Network, a collective action campaign for land-use regularization was the main driver of the regional restoration market, but there are diverse ways to promote commercial opportunities. The local requirements for land restoration of rural settlements in the south Amazon for improving food security and local livelihoods were the motor to establish the Portal network in 2010. The initiative promoted by the partnership between NGOs and small farming associations aimed to achieve the restoration of community degraded lands through agroforestry systems, mostly through funding support (e.g., the Amazon Fund [55]).

Native seed sources are also required by other restoration markets, such as mandatory environmental offset (Law 6.938/1981 [56]), seedling nurseries, environmental campaigns, and voluntary carbon projects. Other examples of seed demand include partnerships of diverse stakeholders to implement restoration actions through compulsory financial investments by extractive industries to mitigate the impacts of their previous illegal operations. This was the main driver for the creation of the Tupygua network in Espírito Santo state in 2012 and the Arboretum in the South of Bahia with the leadership of Brazil's Forest Service in 2015. Meanwhile, a cooperation between environmental agencies, university and research institutes for restoring tropical savannas in Central Brazil has performed experiments and advocated the use of native species with the formation of the Cerrado de Pé Association. Furthermore, more recently the Vale do Ribeira network in the Atlantic Forest is a result of a social movement of the quilombola ('maroons') community together with NGOs to promote the commercial use of agroforestry systems and non-timber products based on the traditional knowledge. Quilombolas are traditional descendants of Africans who escaped from slavery to form independent communities in remote areas.

Community networks are continuously negotiating to create collaboration between diverse stakeholders and long-term partnerships. In these case studies, stakeholders play diverse roles and participate in different levels of decision-making. The commercial arrangement requires mutual planning between seed collectors to inform the harvesting capacity (supply side of the production) and market demands of landowners, nurseries, companies, and projects (seed buyers). NGOs and governmental agencies frequently played the role of linking communities to seed costumers through mapping restoration demand and articulating their relationships. Agreements and contracts are officially established between parties to ensure the ways of the long-lasting commercial collaboration. However, trust is not only a result of signed documents but of a closer negotiation and understanding of each one's responsibilities and rights. The local organizational models also need to attend to the required trading processes and documentation established by regulations (e.g., Law 10,711/2003 [48]). To formalize the seed supply activities, these community networks are adapting the social and productive activities into cooperatives and associations to meet the standard commercial arrangements.

Since seed supply is substantially a community-based activity, local knowledge is the driving force for establishing the local organization and productive systems. Although there are standardized arrangements of how different actors should operate production and trade, seed networks are shaped by place-specific cultural and social norms. Community-based seed suppliers are decentralized, and collectors are organized in autonomous production centers with local leaders to support community organization and decision-making processes. For example, Arboretum joined eight groups linked to local associations or cooperatives with leaders who are responsible for supporting the activities at the community level. The Xingu Seed Network has fourteen groups, each with one local representative responsible for supporting collectors from seed collection to transport. These representatives are also responsible for representing the community during network meetings for decision-making processes.

Social and cultural contexts significantly shape the way that the local community operates the activities. While seed collectors face a lack of infrastructure and specific equipment for seed production, local communities have advanced techniques based on local knowledge. Indigenous, traditional, and rural groups adapt traditional materials available in the villages and develop tools and machines for improving their methods. In the Xingu Seed Network, collectors applied their knowledge to create alternative mechanisms for seed processing. Indigenous people and farmers adapted traditional 
materials for seed collection and processing (Figure 3A-C,F) and developed new equipment to facilitate seed extraction (Figure 3D,E). Collectors of the Portal seed network adapted structures for food processing to seed drying and storage seed lots through using agroecological practices, such as the use of herbs for seed protection against insects and microorganisms. Due to the tall trees in the Atlantic Forest, Arboretum collectors have developed climbing techniques that come together with Indigenous practices. The local innovations improve conditions due to the lack of infrastructure, and at the same time, reinforce the capacity of collectors to find new solutions that do not exist in the large-scale seed industry. Technical development based on local knowledge is critical to address the scarcity of less commercial native species that are commonly not incorporated in restoration projects. For instance, the Cerrado de Pé Network identified and initiated the market supply of 24 native species of grasses, shrubs, and forbs for restoring Neotropical Savannas based on local knowledge and development of seed processing techniques [57].
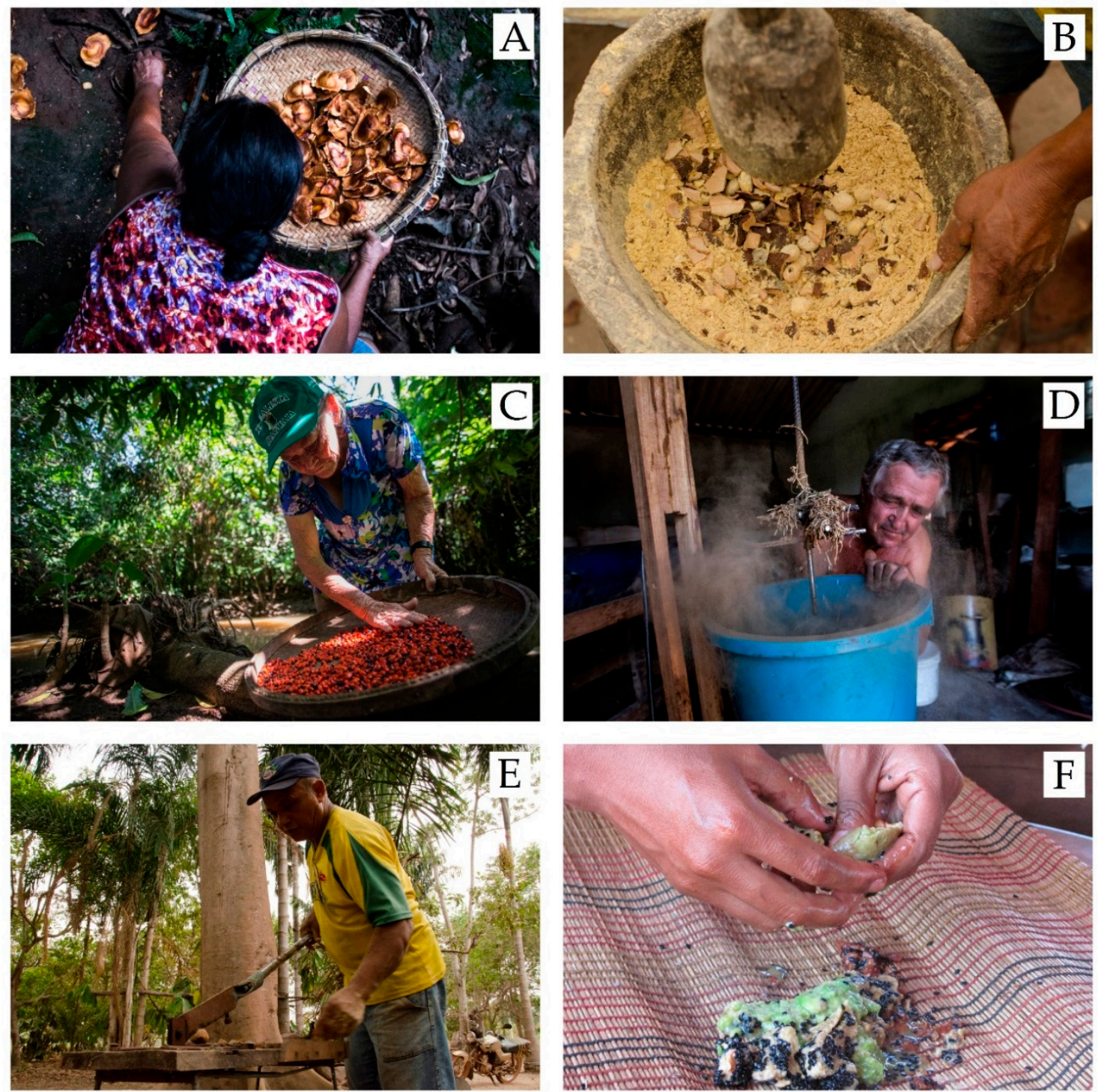

Figure 3. Diverse materials and techniques applied for native seed processing by collectors according to local knowledge and experiences in different Indigenous and rural communities in the Upper Xingu region, covering use of natural fiber basket for seed collection and processing $(\mathbf{A}, \mathbf{C})$; adaptation of pestle (B) and Indigenous matting (F) for seed processing; development of machine (D) and tool (E) for seed extraction. Source: Tui Anandi/ISA. 
Over more than one decade, these six seed networks distributed USD 2.4 million to more than one thousand collectors, generating an average annual financial contribution from the seed trade of USD 285 per collector. Participation in the seed market also impacts diverse livelihood assets with significant place-specific social change. In the case of Portal Network, 120 smallholders of eight different municipalities participate in both seed collection and land restoration with a focus on improving food security through forest production, including seed, fruit, and nut production. In particular, women play a vital role in seed collection in these case studies and represent a significant proportion of contributions to leading processes for both local organization and production activities. The critical evidence for this is the number of women and the specific organizational systems for gender inclusion. Although women's groups for seed collection are very diverse, they share some similarities in terms of promoting opportunities for income generation and involvement in the decision-making process. For instance, women lead the tree seed collection processes in the Kalunga quilombola community in Goiás, and they actively engage in training and meetings of the Cerrado de Pé Association. In the Xingu Seed Network, more than $65 \%$ of the collectors are women, including the Yarang women ( $n=80$ women collectors) of the Ikpeng people in the Upper Xingu. The formation of women's collectives is considered an action to provide more comprehensive systems for negotiating power and the development of community economies [58].

To overcome various knowledge gaps, these community networks have conducted research for technical development to solve local issues. The community networks developed more accessible and less costly techniques to recover ecosystem functionality. One of the critical interventions is the promotion of restoration through direct seeding with a mix of seeds from native and green manure species that are seeded manually or using regular farming machinery, such as spreaders [59]. Intervention in the form of direct seeding have been successfully incorporated in restoration actions in the Upper Xingu [60], Portal da Amazonia and Central of Brazil [61]. In Bahia state, the Arboretum Program has developed the 'Bio-expansion' model, which brings together direct seeding, nucleation, and seedling planting. Consequently, these technical innovations boosted the regional demand of plant material, which reinforces partnership and collaboration for the sustainability of the seed networks.

\subsection{Estimation of Required Native Plant Sources for Large-Scale Restoration}

A range from 2.6 to 25.5 thousand tonnes of seeds would be needed to meet the 12 million hectares of mandatory restoration on private proprieties (Figure 4). The volume of mixed seeds needed to achieve Brazil's restoration goal relies on the first and last step of a restoration techniques-the germination and share of restoration methods. There is a clear difference in the total quantity of native seed required among the five different restoration scenarios, particularly when the direct seeding proportion is increased (more details in Supplementary Materials B). However, there are various intermediate bottlenecks, such as post-seeding/seedling planting predations, diseases, losses by fire, etc. All these issues directly affect the accounting of seed source, and we considered as much as possible in the models (detailed in Supplementary Materials B). In order to be conservative, we assumed as the baseline the medium germination approach, which is the one that presents the largest intersection zone with all the others. Therefore, we consider that Brazil's restoration target requires from 3.6 to 15.6 thousand tonnes of native seed (Figure 4). 


\section{Native seed}

(10 $10^{3}$ tonnes)

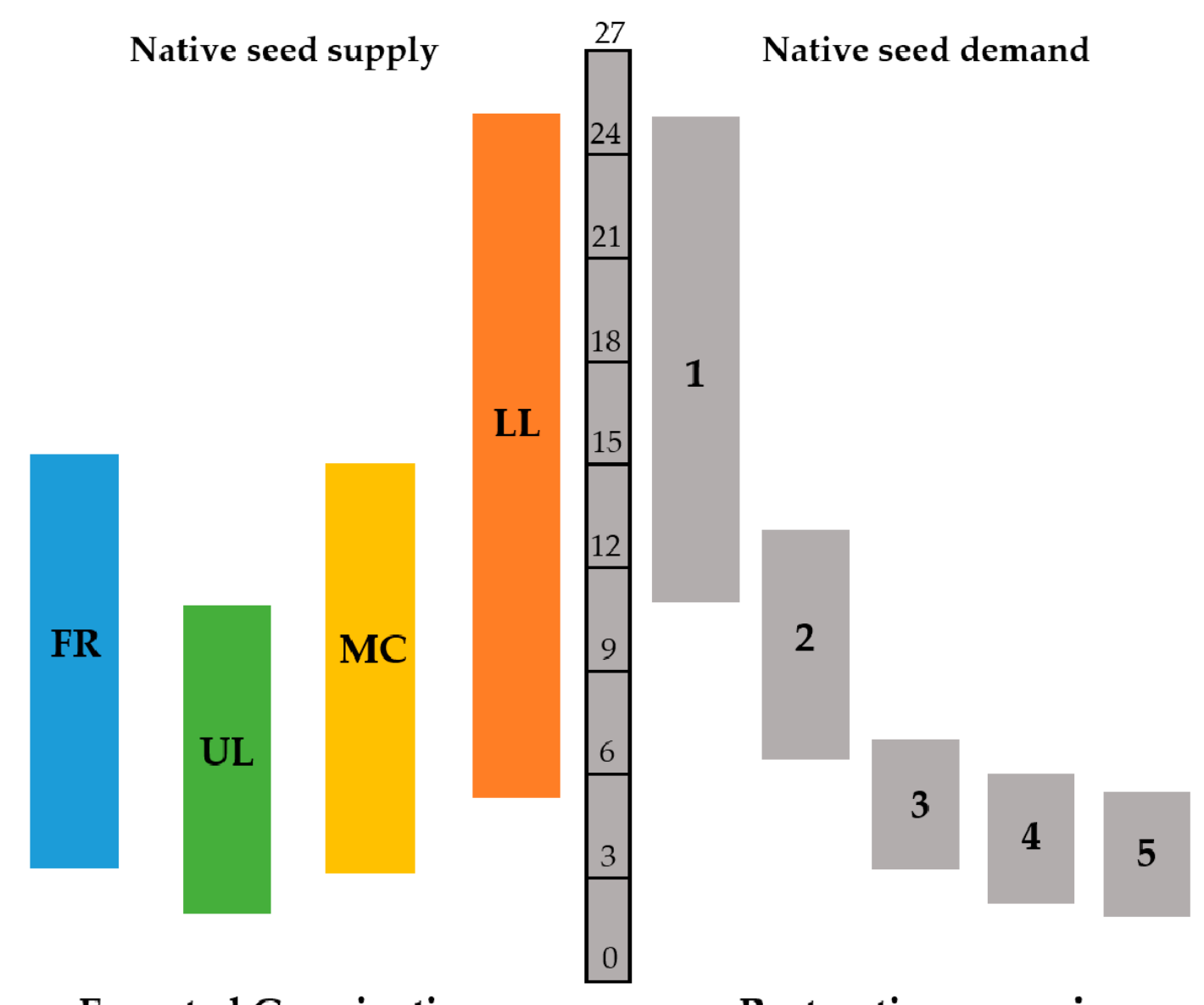

Expected Germination

Restoration scenarios

Figure 4. Native seed sources required to restore 12 million hectares in Brazil. Grey bars represent the restoration scenarios (Table 1), and colored bars represent the range of the seed supply effort, covering the possibilities of Lower Limit Production (LL), Mean Center Production (MC), Upper Limit Production (UL), Full Range Production (FR).

The considerable range of estimated seed demand reveals a major challenge for plant material supply. On average, restoration through seedling enrichment can require around $86 \mathrm{~g}$ of mixed seeds/hectare (i.e., 600 native seedlings/hectare), while direct sowing needs almost 23 kilos/hectare. If we extend our findings to provide a first-ever estimate of the efforts needed to scale up restoration actions, it would need at least 120 seed networks collecting around 50 tonnes of seeds per year to achieve scenario 4 or 560 networks for scenario 1 . The national native seed market for restoration can potentially represent work opportunities for between 13 and 57 thousand people yearly and a total income between USD 34 and 146 million (Table 3). However, these preliminary estimates can vary based on other combinations of restoration methods and seed quality, as well as the social arrangements of collectors. 
Table 3. Estimate of native seeds required to achieve different restoration scenarios in Brazil by 2030.

\begin{tabular}{|c|c|c|c|c|c|c|}
\hline \multirow{2}{*}{$\begin{array}{l}\text { Restoration } \\
\text { Scenario }\end{array}$} & \multicolumn{3}{|c|}{$\begin{array}{c}\text { Restoration Techniques } \\
\left(10^{3} \text { Tonnes of Native Seed }\right)\end{array}$} & \multirow{2}{*}{$\begin{array}{c}\text { Total of } \\
\text { Native Seed } \\
\left(10^{3} \text { tonnes }\right)\end{array}$} & \multirow{2}{*}{$\begin{array}{l}\text { Total Collectors ( } n \text { ) } \\
\text { (Collectors/year) }\end{array}$} & \multirow{2}{*}{$\begin{array}{l}\text { Total Income } \\
\text { (Million USD) }\end{array}$} \\
\hline & $\begin{array}{c}\text { Total } \\
\text { Planting }\end{array}$ & Enrichment & $\begin{array}{c}\text { Direct } \\
\text { Seeding }\end{array}$ & & & \\
\hline 1 & 1.4 & 0.2 & 14.0 & 15.6 & $\begin{array}{l}514,043 \\
(57,116)\end{array}$ & 146.5 \\
\hline 2 & 1.1 & 0.2 & 7.0 & 8.3 & $\begin{array}{l}274,641 \\
(30,516)\end{array}$ & 78.3 \\
\hline 3 & 0.9 & 0.2 & 3.5 & 4.5 & $\begin{array}{l}150,198 \\
(16,689)\end{array}$ & 42.8 \\
\hline 4 & 0.6 & 0.2 & 2.8 & 3.6 & $\begin{array}{l}118,572 \\
(13,175)\end{array}$ & 33.8 \\
\hline 5 & 0.6 & 0.3 & 2.7 & 3.6 & $\begin{array}{l}119,421 \\
(13,269)\end{array}$ & 34.0 \\
\hline
\end{tabular}

\section{Discussion}

\subsection{Risks for Native Seed Supply to Restoration Market}

The current plant supply reality is far short of the need for thousands of tonnes of seed supply identified in our study. However, the scarcity of diverse native seed supply and information is not only of the reality of Brazil, but similar situations are reported in other countries. A global assessment identified that restoration projects in 57 different countries focused mostly on around 6 to 10 different species with various constraints for obtaining high-quality plant materials [17]. Although countries do not adequately examine the official statistics [25], the documentation in the literature demonstrated a critical scenario of the few seed sources available in markets for restoration. The officially native seed supply registered in some developing countries is substantially smaller than what we reported in the six case studies examined in this paper. For example, the annual in-country seed supply is only 300 kilos in Vietnam [19], 8.5 tonnes in Tanzania, and 800 kilos in Zimbabwe [62].

In Brazil, the mandatory demand for landscape restoration is the central driver of the restoration economy. The obligatory restoration on private land provides the most tangible national market for native plant material source, Law 12,651/2012 [36]. However, regulations can and have changed over time, conferring an unstable dynamic for the emergent restoration economy. Although a set of formal institutions has been developed to operate and stimulate this regulation (e.g., the Native Vegetation Protection Policy and Planaveg), the recent national government is dismantling the social-environmental policies $[63,64]$. To fulfil the national mandatory restoration requirement, landowners are responsible for the implementation of restoration that is enforced and monitored through national authorities. This requires a strong coalition between multiple stakeholders, beyond the state power, to promote an alternative mechanism to continue the implementation process and regulations.

Although the native seed supply systems in Brazil have advanced over the last two decades, the mandatory technical and administrative procedures required by the national regulations are among the main barriers limiting the development of the sector. The legal requirements based on commercial farming are enforced to ensure identity, origin, and quality standards based on technical procedures, neglecting the socio-ecological context of community-based seed production. This situation has perpetrated informal channels of native seed and seedling suppliers, not reflected in conventional and legal processes, creating an 'invisible' seed production chain with more than a thousand unregistered collectors and producers (Supplementary Materials A). The regulations were based on standards applied to the agricultural industry, which mainly promote genotype homogeneity and stability as consequences of economic reasoning [65]. However, these mandatory approaches neglected any specifications for the use of genetic and ecological diversity of native species as required for environmental conservation and landscape restoration [24]. 
The difficulties in operating the seed law are also reflected in the vast lack of infrastructure, capacity, and knowledge about the native species. While impressive technological innovation in the crop seed industry has been achieved, covering traceability systems, genetic breeding technology, restricted genetic use, enhancing treatments, and quality standards control [24,31], the centralized regulations based on cultivated species ignore specific demands for community-based suppliers for conservation and restoration actions. This evidence highlights how the formulation of top-down regulations centralized on the state and farming industry constrain local participation for developing a native seed market.

The absence of substantial information about the plant material suppliers is critical because estimating the number of seeds required to implement large-scale programs is not a trivial task. It is challenging to compare our estimate based on community networks ( $30.81 \pm 4.05$ kilos yearly/collector) because of the lack of official databases and documented experiences. Brazil's Institute for Applied Economic Research in 2015 mapped 2117 staff in 230 nurseries but without any specific information about seed collection [66]. Seed production is mostly performed in private nurseries by temporary workers who are hired seasonally for activities like this [52]. Even though these results require further exploration, our analysis reveals the first-ever estimates of the amount of native seed required in Brazil for achieving the large-scale restoration plan. We stress that there are some critical caveats in our estimate of 2.6 to 25 thousand tonnes of native seeds to meet Brazil's restoration. The germination database includes only a few hundred species, while Brazil's flora covers thousands of native species, and the data are considerably varied in terms of the number of seeds per kilogram $(103-586,000)$ and germination rate $(0 \%-96 \%)$. Although the use of median values is appropriate in such cases, the physical and physiological diversity of native species creates enormous challenges in establishing any standards rule. We acknowledge that future advances in seed technology (such as equipment for seed processing and quality tests) could significantly improve the current supply standards. Therefore, all inferences refer to estimates that clearly can and should vary from case to case and place-specific conditions.

\subsection{Opportunities for Native Seed Supply to Large-Scale Restoration}

The restoration of millions of hectares of degraded ecosystems requires a considerable effort combining multiple techniques, from natural regeneration to total seedling planting, multi-purpose interventions, from ecological functionality to commercial forestry, organizational arrangements from community-based to business ventures and different criteria of seeds selection from indigenous to highly selected and genetically improved seeds. In this context of uncertainty, our unprecedented survey on the six major seed networks provides a valuable contribution: First, it encompasses a well-documented database of native seed supply of the three largest Brazilian biomes with a significant demand for restoration.

Seed programs in Brazil have advanced community-based participation in recent decades as a critical intervention to encourage ecosystem restoration with social and economic development. The use and domestication of native seed by Indigenous and traditional peoples in Brazilian landscapes has been a historical resource for food security and cultural reproduction of local practices in these societies [67]. Since Pre-Colombian times, the collection and processing of native plant species has required specific knowledge and abilities from Indigenous people to utilize and develop diverse rainforest products [68]. Unquestionably, local communities in Brazil have the expertise and deep cultural relation with native species, which results in various mechanisms for native plant propagation and cultivation [69], such as the domestication processes of native plants in the Amazon rainforest [36]. However, states and companies have commonly centralized the power for commercial plant material propagation with the appropriation of the genetic resources without the recognition of traditional knowledge or benefit-sharing mechanisms [70].

Income generation through the seed market is a crucial element for promoting local participation, considering the diverse and vulnerable socioeconomic contexts in which rural, Indigenous, and 
traditional communities are immersed. The income contribution of native seeds is significant compared with other cash transfer programs for poverty reduction in Brazil. The average financial resources generated by the seed trade (USD 256.5 per year per collector) can be understood as minimal, however, this amount is relevant for these specific rural contexts, and it is also significant compared with other important cash transfer programs in Brazil. The income generated by seed networks is substantial when compared to Brazil's programs for income transfer and social welfare. For instance, the Bolsa Familia program ('Family Grant') gives benefits to households that can vary (from USD 120 to 600 yearly) based on the family income per person, and the number and age of children [71]. In the context of households in areas of environmental protection, the national Bolsa Verde ('Green Grant') program transfers up to USD 300 annually per household [72]. Although these monetary benefits can be considered very low, programs like Family Grant have been responsible for a significant reduction of poverty in Brazil [73]. Income transfer programs have helped families in vulnerable situations to better access education and health services and breaking the vicious cycle of poverty [74]. We consider that seed collection can be a stimulus for the national programs for transferring income to families living in areas of environmental conservation relevance.

\subsection{Key Strategies for Upscaling Plant Material Supply in Brazil}

The challenge to promote dozen of tonnes of native seed production through the participation of thousands of seed collectors for the national restoration programs requires multi-level governance process with multiple-stakeholders participation. Based on the lessons of the seed networks and the main reasons for the shortage of plant material supply, we identified six key strategies (Figure 5) for a plan to boost native seed supply in Brazil. These strategies are a set of multi-level actions taken by multiple stakeholders that must implemented in order to overcome the current shortage of native seed sources. If these strategies are fully implemented, we consider that seed sector can effectively support important FLR goals.

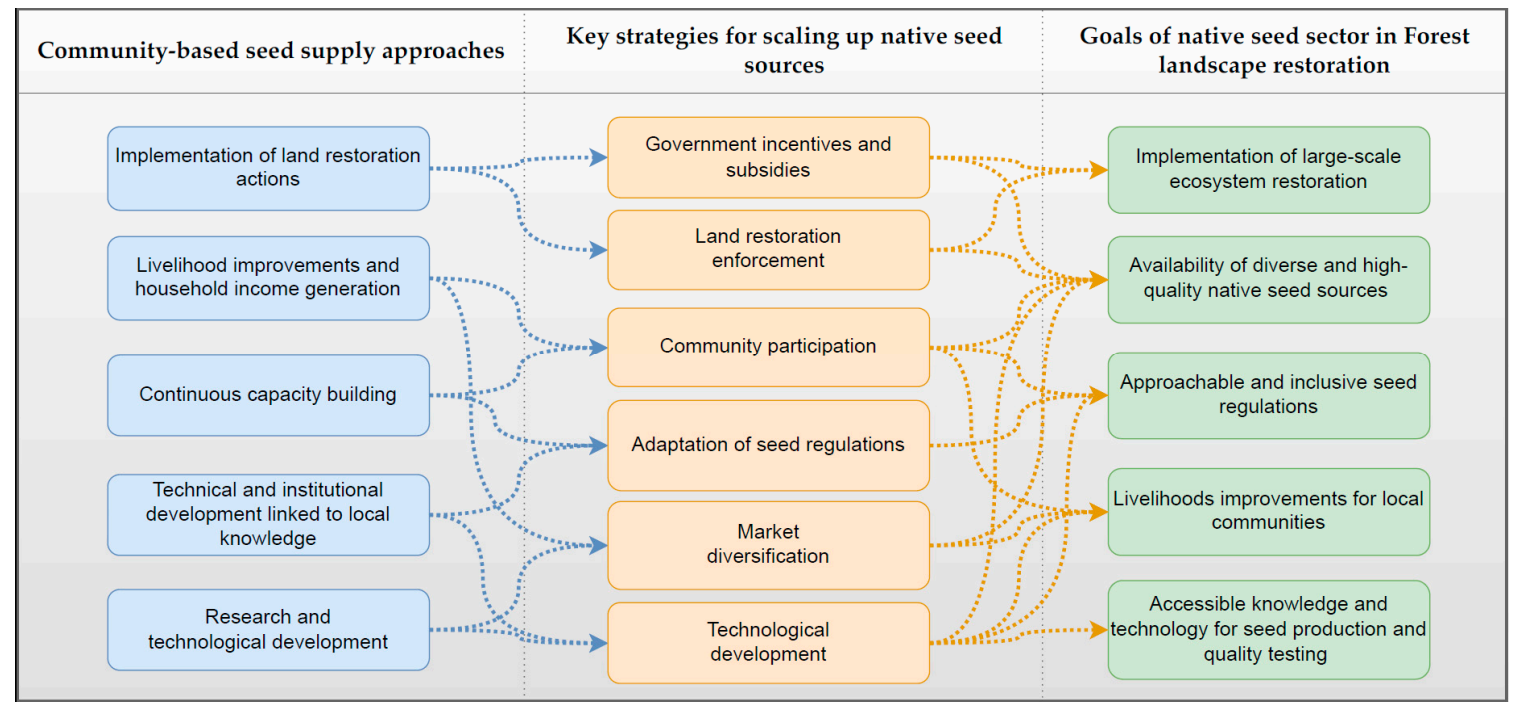

Figure 5. Key strategies for scaling up native seed supply based on the lessons of community-based seed suppliers in Brazil.

\subsubsection{Government Incentives and Subsidies}

We propose a governmental plan which would also purchase seed to support small farmers and local communities to achieve their restoration requirements. Efforts to diversify and scale up native seed production depend to a large extent on adequate and reliable funding for development and, ultimately, on the market [20]. Governmental agencies play a crucial role in promoting funding support and credits to the small producer. The case of the forestry industry in Brazil (briefly described in 
Section 3.1) demonstrated the importance of incentives and subsidies to build a productive sector. For example, tree farming incentivized by governmental policies occupies an area of 9.8 million hectares in Brazil, generating about USD 4 billion yearly [75] and representing 3.5\% of global wood exports [76]. This is a clear demonstration of how state subsidies and investments aligned to technical innovation are essential elements for the implementation of large-scale tree planting programs. In the US, for example, a National Seed Strategy for Rehabilitation and Restoration has been implemented for promoting the restoration economy focused on partnerships among research organizations, public agencies, and enterprises [77]. Supporting the implementation of the Planaveg is central the development of a national native plant material strategy.

\subsubsection{Land Restoration Enforcement}

Since the native seed market is strongly associated with legal restoration requirements, governmental agencies have a central role in enforcing the regulations for upscaling the land restoration in private lands. The maintenance of the national environmental regulations is a primary need to stabilize the restoration economy. These demands demonstrate the importance of creating a coalition with the participation of different actors of society to lead participatory actions. On the other hand, political changes can and have changed how environmental programs are regulated and implemented in Brazil. For example, the political change arising from the Forest Code in 2012-which reduced the sizes of restoration areas in private proprieties [78] — resulted in the closing down of seedlings nurseries. Despite the environmental regulations that have historically been threatened by lobbying from powerful commercial interests, the current Brazilian politics shifted to a polarized attitude against ecosystem conservation and Indigenous rights. Since the election of an ultra-conservative federal government (2019 to 2022), the environmental agenda has suffered a drastic structural dismantling. The government has reacted to pressure on the environmental regulations and Indigenous communities by commercial interest groups encouraged by the changing political situation. Political changes reinforce the vulnerability of restoration markets and the necessity of long-lasting actions with the strong participation of multiple stakeholders to enforce the implementation of the environmental laws. These are critical because seedling nurseries and community-based seed suppliers required a continuous restoration market demand for operating sustainable activities.

\subsubsection{Community Participation}

Scaling up native seed sources requires a multi-scalar negotiation of multiple stakeholders to effectively enforce and implement processes to develop national strategies and actions for FLR. The method of structuring seed programs demonstrates the importance of incorporation of local participation and knowledge for effective operations and outcomes. Community-based native seed production advanced supply systems with significant social benefits that integrate ecosystem restoration, market, and policies. We identified the importance of seed production for promoting local opportunities for local communities to improve local livelihoods and access income. Although Planaveg mentioned the importance of land restoration for generating income, increasing jobs, empowering communities [35], there is a lack of information and political strategies of how these can be effectively applied. Native seed and seedling supply is a tangible way to a win-win approach for promoting local opportunities for well-being improvements and support the execution of large-scale restoration actions.

\subsubsection{Adaptation of the Native Seed Regulations}

Regulatory frameworks for seed quality control can create demand and improve germplasm supply standards for FLR [79]. However, the current formal rules in Brazil constrain native plant material production and trade mainly because of the highly technical approach required to determine seed origin, identity, and quality assurance. Native seeds for ecological restoration must have their specifications for production and marketing certification instead of sharing quality parameters, standard rules, and technical procedures established for improved tree species and crops. For achieving national 
restoration goals, we consider that regulations must be adapted, such as better specified by de Urzedo and collaborators [24].

\subsubsection{Technological Development}

High-quality and diverse plant material sources rely on research and innovations for improving scientific knowledge about native species. Research on seed technology is essential for enhancing seed supply. Strategic research areas include procedures for quality testing (e.g., tetrazolium tests and analyses of image), storage techniques and more effective seeding processes, such as seed coating [80]. Available seed processing equipment is also required to promote more productive supply systems. Moreover, research must explore the knowledge gaps about the seed ecology of native species beyond tree and shrubs species. This information must be translated into practical technical and accessible approaches, such as protocols on how to harvest, process, storage, and quality testing.

\subsubsection{Market Diversification}

Seed markets can also be developed based on different sectors, and industries need to build more substitutional and diverse commercial demands. Pioneer experiences have indicated landscape restoration with commercial purposes for both timber and non-wood products production will be required selected and improved seeds [81]. Tropical forestry in Brazil based on native species can demand plant material, but this market requires specific quality standards. Although there is a significant economic opportunity, there are still legal and financial risks that have inhibited investors for better approaching this matter [82]. Moreover, the industrialization of native seed for other commercial uses can also be a business opportunity for accessing diverse non-timber forest markets, such as oils, nuts, extracts, etc.

\section{Conclusions}

Seed networks in Brazil provide well-documented experience of seed supply, demonstrating their capacity to provide diverse plant material sources with local participation and technological innovations. Community networks promote multiple stakeholders' engagement for linking collectors who have harvested, processed, and stored native seed with regional restoration markets. This supply system has a significant advantage because these networks are primarily in rural areas, close to pristine vegetation, with substantial participation by local people who know the regional biodiversity at the center of the processes. Although community networks promote place-specific actions with a series of particular conditions, we identified essential foundations shared between these seed suppliers. The local stakeholders are responsible as advocates for the consolidation of a stable restoration market of land restoration actions. The seed trade offers relevant opportunities for local communities to improve livelihoods through ecosystem management and household income generation. The experiences of community-based seed suppliers expanded regional knowledge and techniques, including identification of native species, seed collection and processing, and restoration techniques. However, there are considerable gaps in knowledge about native species that have pushed networks to collaborate to develop applied research to address technical issues. These empirical cases demonstrate the capacity of communities to promote large-scale plant material supply. However, the legal framework and governmental programs commonly neglect the role of collectors without specific financial and technical support.

The development of a well-established native seed market for large-scale restoration actions based on diverse species and high-quality standards requires massive investments in infrastructure, technology, and human capacities. Our estimates demonstrate the requirement from 3.6 to 15.6 thousand tonnes of native seed to achieve Brazil's restoration target by 2030. The current national seed and seedling supply system will need to advance the technical process, participation, and foster restoration markets with the inclusion of communities. Seed supply can offer opportunities for economic integration for up to 57 thousand people annually from diverse communities in Brazil through the 
distribution of the maximum total income of USD 146 million based on the restoration economy. Achieving this requires governmental support for establishing a national seed supply plan with specific subsidies and investments aligned to bottom-up approaches for community-based production systems aligned to research and technology development.

There are substantial technical, financial and productive challenges for scaling up restoration efforts. The political dynamics can also be restrictive since regulations in Brazil are the main driver for market demand. The current national government threatens an uncertain future for FLR because of constant deregulation of environmental policies, funding reductions, and lack of law enforcement. On the other hand, the power and decision-making processes for restoration are not solely centralized at the national state level. There are multiple stakeholders developing actions which demonstrate how restoration relies on a hybrid governance system, including subnational governments, international funds, environmental agencies, the private sector, universities, NGOs, communities, and civil society. The case of the seed networks explored in this paper is a clear demonstration of how these stakeholders are performing productive and social processes that lead to more resilient dynamics for ecosystem restoration.

Supplementary Materials: The following are available online at http://www.mdpi.com/1999-4907/11/3/259/s1, Figure S1: Relates the number of original lots (lots) and estimated lots (lots_hat), Figure S2: Two stages Poisson Regression application to estimate the $\mathrm{n}$ sample (lots_hat) as a function of the number of sites (lots) and number of years of collection (years), controlled by the number of seeds available per kilogram of each species (seedskilo), Figure S3. Outputs of panel regressions, Table S1: Number of formal actors for plant material supply in different Brazilian biomes, including native seed collectors, forest seedling nurseries, and seed testing laboratories. Table S2: Simulations to determine the germination rate. (10,000 rounds for each), Table S3. simulations to determine the total seeds per $\mathrm{kg}$ of mixed pack and expected value of germinated seeds per $\mathrm{kg}(10,000$ rounds for each), Table S4. simulations to determine the total $\mathrm{kg}$ of mixed pack to 1 hectare of direct sowing (10,000 rounds for each), Table S5. simulations to determine the total $\mathrm{kg}$ of mixed pack to 1 hectare of seedlings-enrichment $(10,000$ rounds for each), Table S6. simulations to determine the total $\mathrm{kg}$ of mixed pack to 1 hectare of seedlings-total planting (10,000 rounds for each), Table S7. Native seed sources required to meet Brazil's restoration target according to 5 restoration scenarios and the possibilities of Lower Limit Production (LL), Mean Center Production (MC), Upper Limit Production (UL), Full Range Production (FR), Table S8. Primary seed production data from the six major seed networks assessed, Table S9. Germination database of the Institute of Forestry.

Author Contributions: Conceptualization, D.I.d.U., R.F.-B. and R.G.P.J.; Acquisition of the database; D.I.d.U., F.C.M.P.-R. and R.G.P.J.; Data analysis, D.I.d.U., F.C.M.P.-R. and R.F.-B.; Original draft preparation, D.I.d.U.; Writing reviews, D.I.d.U., R.F.-B., F.C.M.P.-R., R.F.; Final editing, R.F.; All authors have read and agreed to the published version of the manuscript.

Funding: The first author was funded by a scholarship from the School of Geosciences-Faculty of Science, The University of Sydney.

Conflicts of Interest: The authors declare no conflict of interest.

\section{References}

1. Tilman, D.; Balzer, C.; Hill, J.; Befort, B.L. Global food demand and the sustainable intensification of agriculture. Proc. Natl. Acad. Sci. USA 2011, 108, 20260-20264. [CrossRef]

2. Gibbs, H.K.; Salmon, J.M. Mapping the world's degraded lands. Appl. Geogr. 2015, 57, 12-21. [CrossRef]

3. Suding, K.; Higgs, E.; Palmer, M.; Callicott, J.B.; Anderson, C.B.; Baker, M.; Gutrich, J.J.; Hondula, K.L.; LaFevor, M.C.; Larson, B.M.H.; et al. Committing to ecological restoration. Science 2015, 348, 638-640. [CrossRef] [PubMed]

4. Griscom, B.W.; Adams, J.; Ellis, P.W.; Houghton, R.A.; Lomax, G.; Miteva, D.A.; Schlesinger, W.H.; Shoch, D.; Siikamäki, J.V.; Smith, P.; et al. Natural climate solutions. Proc. Natl. Acad. Sci. USA 2017, 114, 11645-11650. [CrossRef] [PubMed]

5. Erbaugh, J.T.; Oldekop, J.A. Forest landscape restoration for livelihoods and well-being. Curr. Opin. Environ. Sustain. 2018, 32, 76-83. [CrossRef]

6. WWF and IUCN. Forests Reborn A Workshop on Forest Restoration; IUCN/WWF: Segovia, Spain, 2010.

7. Maginnis, S.; Jackson, W. What Is FLR and How Does It Differ from Current Approaches? In The Forest Landscape Restoration Handbook; Reitbergen-McCracken, S., Maginnis, A.S., Eds.; Earthscan: London, UK, 2007; pp. 5-20. 
8. Lewis, S.; Wheeler, C.E.; Mitchard, E.T.A.; Koch, A. Regenerate natural forests to store carbon. Nature 2019, 568, 25-28. [CrossRef] [PubMed]

9. Rice, J.; Seixas, C.S.; Zaccagnini, M.E.; BedoyaGaitán, M.; Valderrama, N.; Anderson, C.B.; Fennessy, S. Summary for policymakers of the regional assessment report on biodiversity and ecosystem services for the Americas of the Intergovernmental Science-Policy Platform on Biodiversity and Ecosystem Services. IPBES Book 2018, 9, 44.

10. Busch, J.; Engelmann, J.; Cook-Patton, S.C.; Griscom, B.W.; Kroeger, T.; Possingham, H.; Shyamsundar, P. Potential for low-cost carbon dioxide removal through tropical reforestation. Nat. Clim. Chang. 2019, 9, 463-466. [CrossRef]

11. WRI Bonn Challenge|World Resources Institute. Available online: http://www.wri.org/our-work/project/ forest-and-landscape-restoration/bonn-challenge (accessed on 15 March 2017).

12. The New York Declaration on Forests Progress Assess. Protecting and Restoring Forests: A Story of Large Commitments yet Limited Progress. New York Declaration on Forests Five-Year Assessment Report; Climate Focus: Amsterdam, The Netherlands, 2019.

13. COP COP 21 Report. Available online: http://unfccc.int/meetings/paris_nov_2015/session/9057/php/view/ decisions.php (accessed on 15 March 2017).

14. Brancalion, P.H.S.; Niamir, A.; Broadbent, E.; Crouzeilles, R.; Barros, F.S.M.; Almeyda Zambrano, A.M.; Baccini, A.; Aronson, J.; Goetz, S.; Reid, J.L.; et al. Global restoration opportunities in tropical rainforest landscapes. Sci. Adv. 2019, 5, eaav3223. [CrossRef]

15. Chazdon, R.L.; Brancalion, P.H.S.; Lamb, D.; Laestadius, L.; Calmon, M.; Kumar, C. A Policy-Driven Knowledge Agenda for Global Forest and Landscape Restoration. Conserv. Lett. 2017, 10, 125-132. [CrossRef]

16. Adams, C.; Rodrigues, S.T.; Calmon, M.; Kumar, C. Impacts of large-scale forest restoration on socioeconomic status and local livelihoods: What we know and do not know. Biotropica 2016, 48, 731-744. [CrossRef]

17. Jalonen, R.; Valette, M.; Boshier, D.; Duminil, J.; Thomas, E. Forest and landscape restoration severely constrained by a lack of attention to the quantity and quality of tree seed: Insights from a global survey. Conserv. Lett. 2017, 11, 1-9. [CrossRef]

18. Merritt, D.J.; Dixon, K.W. Restoration Seed Banks-A Matter of Scale. Science 2011, 332, 424-425. [CrossRef] [PubMed]

19. Nyoka, B.I.; Roshetko, J.; Jamnadass, R.; Muriuki, J.; Kalinganire, A.; Lillesø, J.P.B.; Beedy, T.; Cornelius, J. Tree Seed and Seedling Supply Systems: A Review of the Asia, Africa and Latin America Models. Small-Scale For. 2014, 14, 171-191. [CrossRef]

20. Oldfield, S.; Olwell, P. The Right Seed in the Right Place at the Right Time. BioScience 2015, 65, 955-956. [CrossRef]

21. Sommerville, K.D.; Clarke, B.; Keppel, G.; McGill, C.; Newby, Z.-J.; Wyse, S.V.; James, S.A.; Offord, C.A. Saving rainforests in the South Pacific: Challenges in ex situ conservation. Aust. J. Bot. 2017, 65, 609. [CrossRef]

22. Lillesø, J.P.B.; Harwood, C.; Derero, A.; Graudal, L.; Roshetko, J.M.; Kindt, R.; Moestrup, S.; Omondi, W.O.; Holtne, N.; Mbora, A.; et al. Why institutional environments for agroforestry seed systems matter. Dev. Policy Rev. 2017, 36, O89-O112. [CrossRef]

23. Nyoka, B.I.; Ajayi, O.C.; Akinnifesi, F.K.; Chanyenga, T.; Mng'omba, S.A.; Sileshi, G.; Jamnadass, R.; Madhibha, T. Certification of agroforestry tree germplasm in Southern Africa: Opportunities and challenges. Agrofor. Syst. 2011, 83, 75-87. [CrossRef]

24. de Urzedo, D.I.; Fisher, R.; Piña-Rodrigues, F.C.M.; Freire, J.M.; Junqueira, R.G.P. How policies constrain native seed supply for restoration in Brazil. Restor. Ecol. 2019, 27, 768-774. [CrossRef]

25. Whiteman, A. Statistics on the production and trade of forest seeds and other forest plant material. In Forestry Statistics and Data Collection-DCA/MISC/02; FAO: Rome, Italy, 2005; p. 28.

26. Walters, C.; Berjak, P.; Pammenter, N.; Kennedy, K.; Raven, P. Preservation of Recalcitrant Seeds. Science 2013, 339, 915-916. [CrossRef]

27. Kindt, R.; Lillesø, J.P.B.; Mbora, A.; Muriuki, J.; Wambugu, C.; Frost, W.; Beniest, J.; Aithal, A.; Awimbo, J.; Rao, S.; et al. Tree Seeds for Farmers: A Toolkit and Reference Source; World Agroforestry Centre: Nairobi, Kenya, 2006.

28. Smith, S. Regional native seed cooperatives: Working toward available, affordable, and appropriate native seed. Nativ. Plants J. 2017, 18, 126-13413. [CrossRef] 
29. Görg, C.; Wittmer, H.; Carter, C.; Turnhout, E.; Vandewalle, M.; Schindler, S.; Livorell, B.; Lux, A. Governance options for science-policy interfaces on biodiversity and ecosystem services: Comparing a network versus a platform approach. Biodivers. Conserv. 2016, 25, 1235-1252. [CrossRef]

30. Nevill, P.G.; Tomlinson, S.; Elliott, C.P.; Espeland, E.K.; Dixon, K.W.; Merritt, D.J. Seed production areas for the global restoration challenge. Ecol. Evol. 2016, 6, 7490-7497. [CrossRef] [PubMed]

31. Schmidt, I.B.; de Urzedo, D.I.; Piña-Rodrigues, F.C.M.; Vieira, D.L.M.; de Rezende, G.M.; Sampaio, A.B.; Junqueira, R.G.P. Community-based native seed production for restoration in Brazil-the role of science and policy. Plant Biol. 2018, 21, 389-397. [CrossRef] [PubMed]

32. Urzedo, D.I.; Vidal, E.; Sills, E.O.; Piña-Rodrigues, F.C.M. Tropical forest seeds in the household economy: Effects of market participation among three sociocultural groups in the Upper Xingu region of the Brazilian Amazon. Environ. Conserv. 2016, 43, 13-23. [CrossRef]

33. Romijn, E.; Coppus, R.; De Sy, V.; Herold, M.; Roman-Cuesta, R.M.; Verchot, L. Land Restoration in Latin America and the Caribbean: An Overview of Recent, Ongoing and Planned Restoration Initiatives and Their Potential for Climate Change Mitigation. Forests 2019, 10, 510. [CrossRef]

34. WRI Initiative 20×20. Available online: https://www.wri.org/our-work/project/initiative-20x20 (accessed on 27 February 2020).

35. Ministério do Meio Ambiente. Brazil Planaveg: Plano Nacional de Recuperação da Vegetação Nativa; Ministério do Meio Ambiente: Brasília, Brazil, 2017; p. 76.

36. Brazil Law No 12,651-Protection of the Native Vegetation. Available online: http://www.planalto.gov.br/ ccivil_03/_ato2011-2014/2012/lei/112651.htm (accessed on 11 October 2018).

37. Piña-Rodrigues, F.C.M.; Nogueira, E.S.; Peixoto, M.C.; Reis, L.L. Estado da arte da produção de sementes de espécies florestais na Mata Atlântica. In Parâmetros Técnicos Para a Produção de Sementes Florestais; Pina-Rodrigues, F.C.M., Freire, J.M., Leles, P.S.S., Breier, B.B., Eds.; EDUR-UFRRJ: Seropédica, Brazil, 2007; pp. 11-34, ISBN 9788585720582.

38. Pizo, M.A. Seed dispersal and predation in two populations of Cabralea canjerana (Meliaceae) in the Atlantic Forest of southeastern Brazil. J. Trop. Ecol. 1997, 13, 559-577. [CrossRef]

39. Vaz Ferreira, A.; Bruna, E.M.; Vasconcelos, H.L. Seed predators limit plant recruitment in Neotropical savannas. Oikos 2011, 120, 1013-1022. [CrossRef]

40. Dalling, J.W.; Swaine, M.D.; Garwood, N.C. Dispersal patterns and seed bank dynamics of pioneer trees in moist tropical forest. Ecology 1998, 79, 564-578. [CrossRef]

41. Hulme, P.E.; Benkman, C.W. Granivory. In Plant-Animal Interactions: An Evolutionary Approach; Pellmyr, C.H.O., Ed.; Blackwell Scientific Publications: New York, NY, USA, 2000; pp. 132-154.

42. Ferreira, M. Melhoramento e a silvicultura intensiva clonal. Série Técnica IPEF 1992, 45, 22-30.

43. Brazil Law 5,106-Tax Incentives for Forestry Sector. Available online: http://www2.camara.leg.br/legin/fed/ lei/1960-1969/lei-5106-2-setembro-1966-368482-normaatualizada-pl.html (accessed on 11 October 2018).

44. Rio de Janeiro Botanic Garden Brazilian Flora 2020. Available online: http://floradobrasil.jbrj.gov.br/ (accessed on 7 December 2017).

45. Ferreira, M. A aventura dos eucaliptus. In Silvicultura do Eucalipto no Brasil; Schumacher, M., Viera, M., Eds.; Editora UFSM: Santa Maria, Philippines, 2016; pp. 11-46.

46. Rossato, F.G.; Susaeta, A.; Adams, D.C.; Hidalgo, I.G.; de Araujo, T.D.; de Queiroz, A. Comparison of revealed comparative advantage indexes with application to trade tendencies of cellulose production from planted forests in Brazil, Canada, China, Sweden, Finland and the United States. For. Policy Econ. 2018, 97, 59-66. [CrossRef]

47. Brazil Lei de Inspeção e a Fiscalização Da Produção e Do Comércio de Sementes e Muda. Available online: http://www.planalto.gov.br/ccivil_03/LEIS/1970-1979/L6507.htm (accessed on 12 February 2020).

48. Brazil Sistema Nacional de Sementes e Mudas. Available online: http://sistemasweb.agricultura.gov.br/ renasem/ (accessed on 27 February 2020).

49. Brazil Law No 4,771-The Brazilian Forest Code. Available online: http://www2.camara.leg.br/legin/fed/lei/ 1960-1969/lei-4771-15-setembro-1965-369026-publicacaooriginal-1-pl.html (accessed on 11 October 2018).

50. Chazdon, R.L. Beyond deforestation: Restoring forests and ecosystem services on degraded lands. Science 2008, 320, 1458-1460. [CrossRef] [PubMed]

51. Zahawi, R.A.; Holl, K.D. Comparing the Performance of Tree Stakes and Seedlings to Restore Abandoned Tropical Pastures. Restor. Ecol. 2009, 17, 854-864. [CrossRef] 
52. Moreira da Silva, A.P.; Schweizer, D.; Rodrigues Marques, H.; Cordeiro Teixeira, A.M.; Nascente dos Santos, T.V.M.; Sambuichi, R.H.R.; Badari, C.G.; Gaudare, U.; Brancalion, P.H.S. Can current native tree seedling production and infrastructure meet an increasing forest restoration demand in Brazil? Restor. Ecol. 2016, 25, 509-515. [CrossRef]

53. Durigan, G.; Guerin, N.; da Costa, J.N.M.N. Ecological restoration of Xingu Basin headwaters: Motivations, engagement, challenges and perspectives. Philos. Trans. R. Soc. Lond. Ser. BBiol. Sci. 2013, 368, 20120165. [CrossRef]

54. Brazil Decreto, no. 6.040-Política Nacional de Desenvolvimento Sustentável dos Povos e Comunidades Tradicionais. Available online: http://www.planalto.gov.br/ccivil_03/_ato2007-2010/2007/decreto/d6040.htm (accessed on 27 February 2020).

55. MMA. Amazon Fund. Available online: http://www.amazonfund.gov.br/en/home/ (accessed on 27 February 2020).

56. Brazil Lei $n^{\circ}$ 6.938 - Política Nacional Do Meio Ambiente. Available online: http://www.planalto.gov.br/ ccivil_03/LEIS/L6938.htm (accessed on 27 February 2020).

57. Pellizzaro, K.F.; Cordeiro, A.O.O.; Alves, M.; Motta, C.P.; Rezende, G.M.; Silva, R.R.P.; Ribeiro, J.F.; Sampaio, A.B.; Vieira, D.L.M.; Schmidt, I.B. “Cerrado" restoration by direct seeding: Field establishment and initial growth of 75 trees, shrubs and grass species. Braz. J. Bot. 2017, 40, 681-693. [CrossRef]

58. Shackleton, S.; Paumgarten, F.; Kassa, H.; Husselman, M.; Zida, M. Opportunities for enhancing poor women's socioeconomic empowerment in the value chains of three African non-timber forest products (NTFPs). Int. For. Rev. 2011, 13, 136-151. [CrossRef]

59. Campos-Filho, E.M.; Da Costa, J.N.M.N.; Sousa, O.; Junqueira, R.G.P.; Da Costa, J.N.M.N.; De Sousa, O.L.; Junqueira, R.G.P. Mechanized Direct-Seeding of Native Forests in Xingu, Central Brazil. J. Sustain. For. 2013, 32, 702-727. [CrossRef]

60. Freitas, M.G.; Rodrigues, S.B.; Campos-Filho, E.M.; do Carmo, G.H.P.; da Veiga, J.M.; Junqueira, R.G.P.; Vieira, D.L.M. Evaluating the success of direct seeding for tropical forest restoration over ten years. For. Ecol. Manag. 2019, 438, 224-232. [CrossRef]

61. Sampaio, A.B.; Vieira, D.L.M.; Holl, K.D.; Pellizzaro, K.F.; Alves, M.; Coutinho, A.G.; Cordeiro, A.; Ribeiro, J.F.; Schmidt, I.B. Lessons on direct seeding to restore Neotropical savanna. Ecol. Eng. 2019, 138, 148-154. [CrossRef]

62. FAO State of Forest and Tree Genetic Resources in Dry Zone Southern Africa Development Community Countries. Available online: http://www.fao.org/3/ac850e/ac850e00.htm\#Contents (accessed on 24 February 2020).

63. Abessa, D.; Famá, A.; Buruaem, L. The systematic dismantling of Brazilian environmental laws risks losses on all fronts. Nat. Ecol. Evol. 2019, 3, 510-511. [CrossRef] [PubMed]

64. Levis, C.; Flores, B.M.; Mazzochini, G.G.; Manhães, A.P.; Campos-silva, J.V.; De Amorim, P.B.; Peroni, N.; Hirota, M.; Clement, C.R. Help restore Brazil' s governance of globally important ecosystem services. Nat. Ecol. Evol. 2020, 4, 172-173. [CrossRef] [PubMed]

65. Khoury, C.K.; Bjorkman, A.D.; Dempewolf, H.; Ramirez-Villegas, J.; Guarino, L.; Jarvis, A.; Rieseberg, L.H.; Struik, P.C. Increasing homogeneity in global food supplies and the implications for food security. Proc. Natl. Acad. Sci. USA 2014, 111, 4001-4006. [CrossRef] [PubMed]

66. Silva, A.P.M.; Marques, H.R.; dos Santos, T.V.M.N.; Teixeira, A.M.C.; Sambuichi, R.H.R.; Luciano, M.S. Ferreira Diagnóstico da Produção de Mudas Florestais Nativas no Brasil. Available online: http://repositorio. ipea.gov.br/bitstream/11058/7515/1/RP_Diagn\%c3\%b3stico_2015.pdf (accessed on 24 February 2020).

67. Labouriau, F.L. The Interest in Seed Studies. Organ. Am. States 1990, 9, 1-12.

68. Lévis-Strauss, C. The Use of Wild Plants in Tropical South America x. Econ. Bot. 1952, 6, 252-270. [CrossRef]

69. Carneiro Cunha, M.C.; Morim de Lima, A.G. How Amazonian Indigenous Peoples enhance Biodiversity. In Knowing our Lands and Resources: Indigenous and Local Knowledge of Biodiversity and Ecosystem Services in the Americas. Knowledges of Nature; Baptiste, B., Pacheco, D., da Cunha, M.C., Diaz, S., Eds.; UNESCO: Paris, France, 2017; pp. 1-22.

70. Levis, C.; Flores, B.M.; Moreira, P.A.; Luize, B.G.; Alves, R.P.; Franco-Moraes, J.; Lins, J.; Konings, E.; Peña-Claros, M.; Bongers, F.; et al. How people domesticated Amazonian forests. Front. Ecol. Evol. 2018. [CrossRef] 
71. Brazil Bolsa Família-Programas Sociais-Caixa. Available online: http://www.caixa.gov.br/programassociais/bolsa-familia/paginas/default.aspx (accessed on 11 January 2020).

72. MMA Bolsa. Available online: https://www.mma.gov.br/biomas/caatinga/iniciativas-de-uso-sustentável/ itemlist/category/74-bolsa-verde.html (accessed on 11 January 2020).

73. Soares, F.V.; Ribas, R.P.; Osorio, R. Evaluating the Impact of Brazil's Bolsa Família: Cash Transfer Programs in Comparative Perspective. Latin Am. Res. Rev. 2010, 45, 173-190.

74. Mourão, L.; de Jesus, A.M. Bolsa família (Family Grant) programme: An analysis of Brazilian income transfer programme. Field Actions Sci. Rep. 2012, 4, 43-49.

75. IBGE Resultados do Censo Agro 2017. Available online: https://censoagro2017.ibge.gov.br/templates/censo_ agro/resultadosagro/pecuaria.html (accessed on 29 May 2019).

76. World Bank Brazil Wood Exports By Country 2017. Available online: https://wits.worldbank.org/ CountryProfile/en/Country/BRA/Year/2017/TradeFlow/Export/Partner/by-country/Product/44-49_Wood/ Show/PartnerName;XPRT-TRD-VL;XPRT-PRDCT-SHR;/Sort/XPRT-TRD-VL/Chart/top10 (accessed on 11 January 2020).

77. Camhi, A.L.; Perrings, C.; Butterfield, B.; Wood, T. Market-based opportunities for expanding native seed resources for restoration: A case study on the Colorado Plateau. J. Environ. Manag. 2019, 252, 109644. [CrossRef]

78. Soares-Filho, B.; Rajão, R.; Macedo, M.; Carneiro, A.; Costa, W.; Coe, M.; Rodrigues, H.; Alencar, A. Cracking Brazil's Forest Code. Science 2014, 344, 363-364. [CrossRef]

79. Jalonen, R.; Thomas, E.; Cavers, S.; Bozzano, M.; Boshier, D.; Bordács, S.; Gallo, L.; Smith, P.; Loo, J. Analysis of genetic considerations in restoration methods. In Genetic Considerations in Ecosystem Restoration Using Native Tree Species. State of the World's Forest Genetic Resources; Bozzano, M., Jalonen, R., Thomas, E., Boshier, D., Gallo, L., Cavers, S., Bordács, S., Smith, P., Loo, J., Eds.; FAO and Bioversity International: Rome, Italy, 2014; pp. 245-274.

80. Pedrini, S.; Merritt, D.J.; Stevens, J.; Dixon, K. Seed Coating: Science or Marketing Spin? Trends Plant Sci. 2017, 22, 106-116. [CrossRef] [PubMed]

81. Batista, A.; Pradom, A.; Pontes, C.; Matsumoto, M. Verena Investment Tool: Valuing Reforestation with Native Tree Species and Agroforestry Systems; WRI Brasil: São Paulo, Brazil, 2017.

82. Faruqi, S.; Wu, A.; Brolis, E.; Ortega, A.A.; Batista, A. The Business of Planting Trees: A Growing Investment Opportunity; WRI: Washington, DC, USA, 2018.

(C) 2020 by the authors. Licensee MDPI, Basel, Switzerland. This article is an open access article distributed under the terms and conditions of the Creative Commons Attribution (CC BY) license (http://creativecommons.org/licenses/by/4.0/). 